\title{
Trend Analysis of Coffee (Coffea Arabica L.) Productivity, Area of Production and Numbers of Holders in Ethiopia
}

\author{
Wasihun Gizaw Fantaye \\ Oromia Agriculture Research Institute, Ethiopia P.O. Box 81265, Addis Abeba
}

\begin{abstract}
This study was undertaken to identify trends of; Coffee (Coffea Arabica L.) productivity, area of production and numbers of holders of coffee in Ethiopia. Data of; annual coffee yield, area of production and numbers of holders of coffee in Ethiopia for the period 2006/2007-2017/2018 were collected from Central statistical Agency (CSA). Trend test were carried out using the non-parametric Mann-Kendall's trend test using xlstat software. The result of this study indicated that the country level area of coffee production showed significant increasing trend by a factor of 40534.67 ha per year. Similarly, numbers of holders/producers in the country were increased significantly by the factors of 283169.2 holders/year. Moreover country level annual total amount of coffee Production were showed significant increasing trend by the factor of $219787.1 \mathrm{qt} / \mathrm{year}$ over the study periods. Despite expansions of coffee production area coverage and increasing numbers of holders in the country, however, the trend of coffee productivity in the country showed non-significant decreasing trend by the factors of $-0.176 \mathrm{qt} / \mathrm{ha}$ per year for study periods. Therefore, the author of this work have recommend that, land suitability of this crop at which it has been expanded in the country and others reasons behind decreasing productivity of this crop has to study

DOI: $10.7176 / \mathrm{JNSR} / 9-15-01$
\end{abstract}

Publication date: August $31^{\text {st }} 2019$

\section{INTRODUCTION}

Coffee is a perennial field crop which belongs to the genus Coffea in the Rubiaceae family, and is mostly grown in the tropical and subtropical regions (Berthaud and Charrier, 1988). Coffee is the world's most important tropical export crop but recent studies predict severe climate change impacts on Coffea arabica (C. arabica) production (Craparo et al., 2015). Among coffee species, only two species, Coffea Arabica L. (Arabica coffee) and Coffea canephora (Robusta coffee) economically dominate the world coffee trade (ICC, 2009; Damatta and Ramalho, 2006). Predominately, Arabica represents 70\% of global coffee praoduction and Robusta represents about 30\% (Damatta and Ramalho, 2006; Davis et al., 2012).

Ethiopia is the home and cradle of biodiversity of Arabica coffee seeds and also it is the center for origin, diversification, and dissemination of the Arabica coffee plant (Bayetta, 2001) Ethiopia produces only Arabica coffee which is considered as superior to Robusta coffee due to its fine aroma, strong body, and pleasant acidity (Zewdu, 2016). The coffee production sector in Ethiopia is being supported by both Regional and Federal Governments (Berhanu, 2017). The country produces premium quality Arabica coffee in Africa and is the third largest producer in the world (ICO, 2014). A quarter of the total population of Ethiopia is directly or indirectly dependent on the income they generate from growing coffee for their livelihood (Zewdu,2016). In Ethiopia, the coffee is produced within specific agro-ecological zones, in several geographical and political boundaries. The main coffee-production areas of Ethiopia are the south-west and south-east, with modest and minor production in the north part of the country. According to Davis et al., (2017), stated that "coffee production had been negatively influenced by changes in climate". Coffee produced in different production systems that include forest, semi-forest, garden, and a modern plantation. There are differences of opinion on the amount of farm size for coffee production area by smallholders. More than 90 percent of coffee produced in the country comes from smallholder farmers, and the rest 10 percent is from medium and large scale producers (USDA, 2016). The majority of production is on the small garden field and on average less than 2 hectares with yields remaining low at around $0.7-0.8$ metric tons per hectare (USDA, 2016). The production is mainly by smallholder farmers on average reported about 0.67 ha. According to CSA (2017), the estimated area of land covered by coffee in Ethiopia is about 700474.69 ha, whereas the estimated annual national production of clean coffee is about 469091.12 tons with average productivity of $669.6 \mathrm{~kg} \mathrm{ha}^{-1}$. Despite the high production potential and economic importance of coffee production and productivity of this crop, nowadays producers are suffering from poor productivity and replacing it by other crops. Many farmer particular in parts of kaffa and Ilulbabor were forced to cut or up root the coffee plants in order to grow food crops (Arega, 2006).

Climatic variability has always been the main factor responsible for the reduction of coffee yields in the world and determines the future coffee production status in the coffee producer's countries (Kasterine et al., 2010). Climate variation is the most favorable for increase of coffee pest disease; the loss estimate globally is $13 \%$ of yield reduction (Agegnehu et al., 2015). Major disease that occurred because of climate variation during coffee growing will increase pest and disease prevalence, expanding the altitudinal range in which the fungal disease coffee rust and the coffee berry borer can survive (Läderach et al., 2010). For example, rising temperatures will 
increase infestation by the Coffee berry borer (Hypothenemus hampeii), particularly where coffee grows un shaded and the cropping is continuous throughout the year (Walyaro, 2010). Jaramillo et al. (2011) predicted that climate change would worsen pest prevalence like "broca" (berry borer) in Eastern Africa. Consequences of this event suffer viability of current high quality producers (Kasterine et al., 2010). Climate change increases need for fungicides and lead to a resurgence of certain pests and diseases on coffee (Gianessi and Williams, 2011). In the case study of Colombia and Ethiopia, an increase in rainfall and temperature threatens the coffee at an alarming rate, respectively and is more conducive, for pests and disease prevalence (Iscaro, 2014).

According to Killeen and Harper (2016) reveals coffee production area changed because suitable areas becomes too warm or prone to periodic drought (Killeen and Harper, 2016). Most suitable area becomes unsuitable because of climate variation (Dekens and Bagamb, 2014).Similarly in Ethiopia small holder farmers are suffering from poor productivity of this crop. Therefore, the main objective of this review is to analysis trends of; Coffee (Coffea Arabica L.) productivity, area of production and numbers of holders in Ethiopia.

\section{MATERIALS AND METHODS}

Data of; annual coffee yield, area of production and numbers of holders of coffee in Ethiopia for the period 2006/2007-2017/2018 were collected from Central statistical Agency (CSA).

Trend test were carried out using the non-parametric Mann-Kendall's trend test which is less sensitive to outliers and test for a trend in a time series without specifying whether the trend is linear or non-linear (Partal and Kahya, 2006; Yenigun et al., 2008; Hadgu et al.,2013). The Mann-Kendall's test statistic is given as:

$S=\sum_{i=1}^{N-1} * \sum_{j=i+1}^{N} \operatorname{sgn}\left(x_{j}-x_{i}\right)$ equation (1)

Where $\mathrm{S}$ is the Mann-Kendal's test statistics; $x_{\mathrm{i}}$ and $x_{\mathrm{j}}$ are the sequential data values of the time series in the years $i$ and $j(j>i)$ and $N$ is the length of the time series. A positive $S$ value indicates an increasing trend and a negative value indicates a decreasing trend in the data series. The sign function is given as

$\operatorname{sgn}\left(x_{j-} x_{x}\right)=\left\{\begin{array}{ccc}+1 \text { if } & \left(x_{j-} x_{i}\right)>0 \\ 0 \text { if } & \left(x_{j}-x_{i}\right)=0 \\ -1 \text { if } & \left(x_{j-} x_{i}\right)<1\end{array}\right\}$

equation (2)

The variance of $S$, for the situation where there may be ties (i.e., equal values) in the $x$ values:

$\operatorname{var}(\mathrm{S})=\frac{1}{18}\left[N(N-1)(2 n+5)-\sum_{i=1}^{m} t_{i}\left(t_{i}-1\right)\left(2 t_{i}+5\right)\right] \quad$ equation (3)

Where, $m$ is the number of tied groups in the data set and $t_{i}$ is the number of data points in the $i^{\text {th }}$ tied group. For $\mathrm{n}$ larger than 10, $\mathrm{Z}_{\mathrm{MK}}$ approximates the standard normal distribution (Partal and Kahya, 2006; Yenigun et al., 2008) and computed as follows

$Z_{M K}=\left\{\begin{array}{cll}\frac{s-1}{\sqrt{\operatorname{var}(S)}} & \text { if } & S>0 \\ 0 & \text { if } & S=0 \\ \frac{S+1}{\sqrt{\operatorname{var}(S)}} & \text { if } & S<0\end{array}\right\}$

equation (4)

The presence of significant trend is evaluated using the $Z_{M K}$ value. In a two-sided test for trend, the null hypothesis $H o$ should be accepted if $Z_{M K}<Z_{1-\alpha / 2}$ at a given level of significance. $Z_{1-\alpha / 2}$ is the critical value of $Z_{\mathrm{MK}}$ from the standard normal table.

\section{RESULTS AND DISCUSSIONS}

Table 1. Area and production (smallholder farms, Meher season) average over 2006/07-2017/18

\begin{tabular}{ccccc} 
Years & Area in hectors & Numbers of holders & Production in quintals & Yield (qt/ha) \\
\hline $2006 / 2007$ & 295238 & 2948665 & 2414824 & 8.24 \\
$2007 / 2008$ & 407147.1 & 3499219 & 2734001 & 6.72 \\
$2010 / 2011$ & 498617.9 & 3854931 & 3705694 & 7.43 \\
$2011 / 2012$ & 515882.5 & 4042237 & 3768232 & 7.30 \\
$2012 / 2013$ & 528751.1 & 4217961 & 3739406 & 7.07 \\
$2013 / 2014$ & 538466.8 & 4546785 & 3920062 & 7.28 \\
$2014 / 2015$ & 561761.8 & 4723483 & 4199802 & 7.48 \\
$2015 / 2016$ & 653909.8 & 5270777 & 4145965 & 6.34 \\
$2016 / 2017$ & 700474.7 & 6455194 & 4690911 & 6.7 \\
$2017 / 2018$ & 725961.2 & 5019513 & 4492298 & 6.19 \\
\hline
\end{tabular}



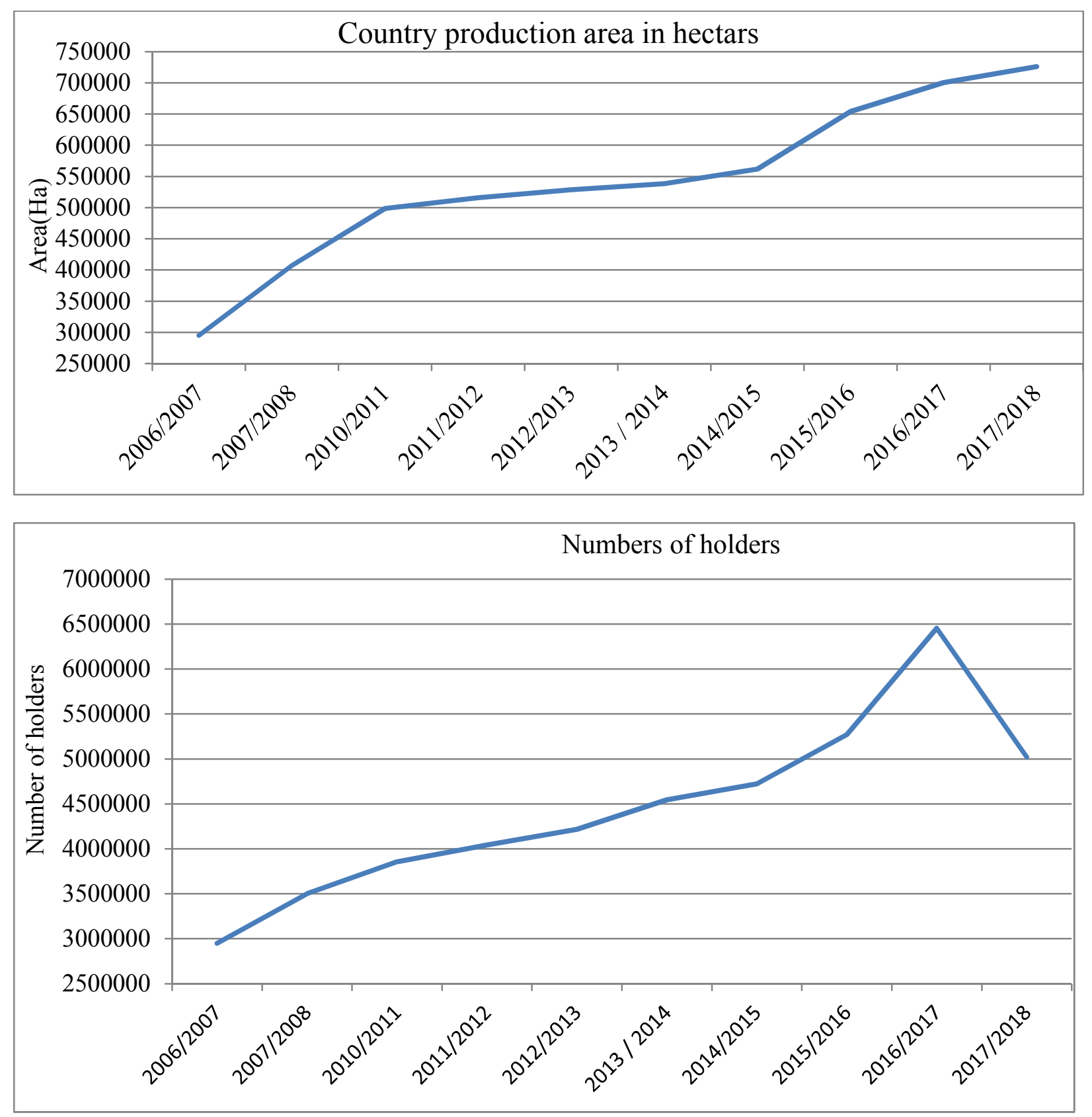

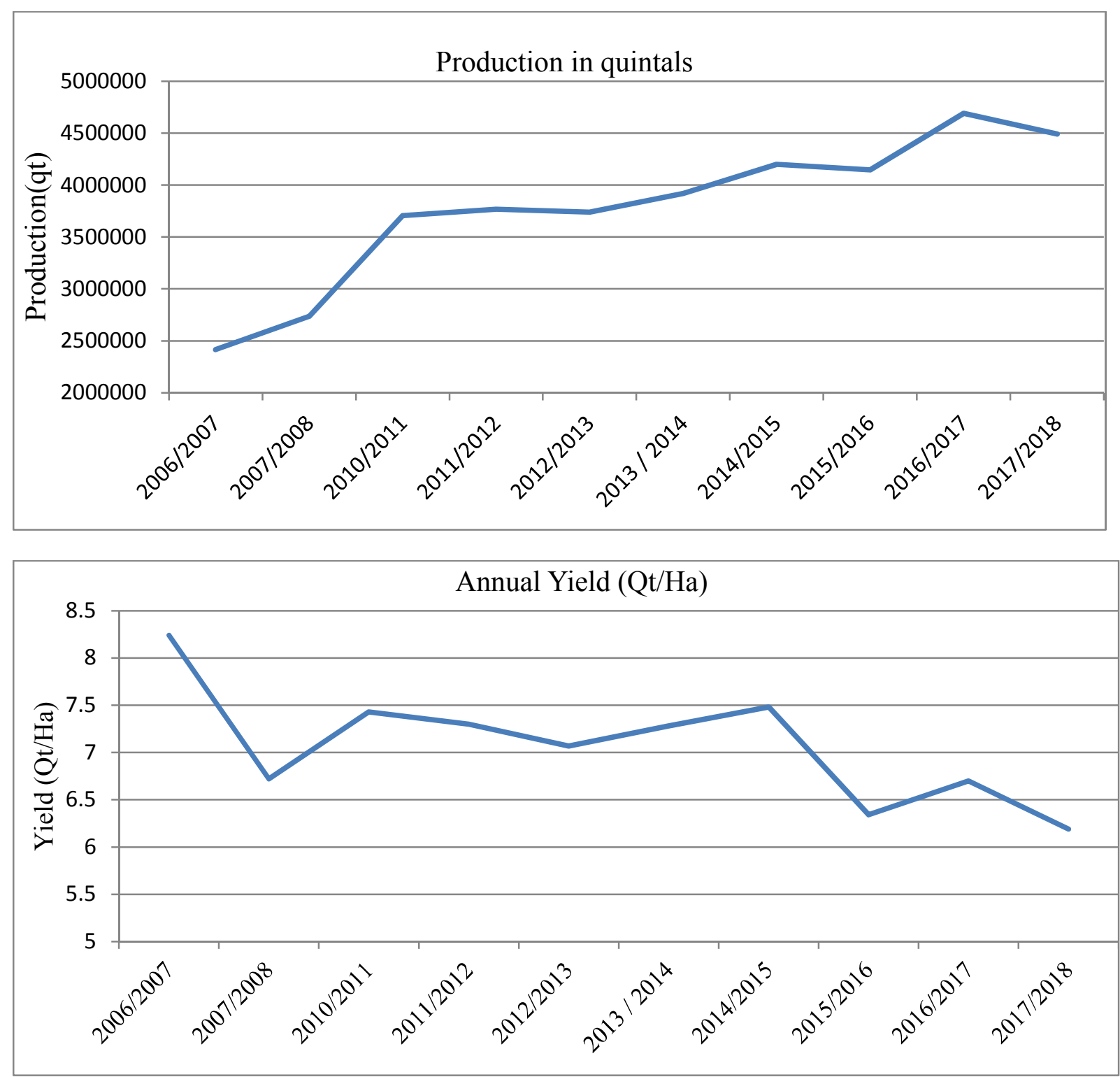

Table 2.Mann-Kendall trend statistics for monthly, seasonal and annual rainfall total

\begin{tabular}{lccccc}
\hline Variables & $\mathrm{Z}_{\mathrm{mk}}$ & MK statistic(S) & alpha & Sun's slope & p-value \\
\hline Area of production (ha) & 1.00 & 45 & 0.05 & 40534.67 & $<0.0001$ \\
Numbers of holders & 0.91 & 41 & 0.05 & 283169.2 & $<0.0001$ \\
Production (qt) & 0.87 & 39 & 0.05 & 219787.1 & 0.0001 \\
yield(qt/ha)) & -0.51 & -23 & 0.05 & -0.176 & 0.0466 \\
\hline
\end{tabular}

Sen's slope value in Table 2 above indicated that the country level area of coffee production showed significant $(<0.0001)$ increasing trend by a factor of 40534.67 ha per year. This indicated coffee production in the country has been expanded in area of production. Numbers of holders in the country were increased significantly $(<0.0001)$ by the factors of 283169.2 small holders/year. This indicates that coffee has been familiarized to either new area or new producers and so that coffee producers in the country were increased from year to year. Country level annual total amount of coffee Production were showed significant $(p=0.0001)$ increasing trend by the factor of $219787.1 \mathrm{qt} / \mathrm{year}$ over the study periods. This is because of expansion of production area and increments in numbers of producers in the country.

Despite expansions of coffee production area coverage and increasing numbers of holders in the country, however, the trend of coffee productivity in the country showed non-significant $(p=0.0466)$ decreasing trend by the factors of $-0.176 \mathrm{qt} /$ ha per year for 2006/2007-2017/2018 intervals. Many studies agree with this reduction of coffee productivity/yield based on different justifications for example, according to Kasterine et al. (2010), 
Climatic variability has always been the main factor responsible for the reduction of coffee yields in the world and determines the future coffee production status in the coffee producer's countries. Similarly, According to Davis et al., (2017), stated that "coffee production had been negatively influenced by changes in climate". coffee produced in different production systems that include forest, semi-forest, garden, and a modern plantation. Moreover, according to Dekens and Bagamb (2014) climate variations affect coffee industry from production to export).

Killeen and Harper (2016) result revealed that, coffee production area changed because suitable areas becomes too warm or prone to periodic drought (Killeen and Harper, 2016). Most suitable area becomes unsuitable because of climate variation (Dekens and Bagamb, 2014. Despite the high production potential and economic importance of coffee production and productivity of this crop in Ethiopia, nowadays producers are suffering from poor productivity and replacing it by other crops. Many farmer particular in parts of kaffa and Ilulbabor were forced to cut or up root the coffee plants in order to grow food crops (Arega, 2006).

\section{RECOMMENATIOS}

Result of this study indicated that, a decreasing trend of productivity of coffee at country level regardless of increasing trend of coffee production area and numbers of holders. Therefore, the author of this work have recommend that, land suitability of this crop at which it has been expanded in the country has to study. And also further study reasons behind reduction of productivity of this crop have to undertake.

\section{REFERANCES}

Agegnehu E, Thakur A, Mulualem T. 2015. Potential Impact of Climate Change on Dynamics of Coffee Berry Borer (Hypothenemus hampi Ferrari) in Ethiopia. Open Access Library J. 2(01):1.

Arega Z.2006. Diversity of Arabica coffee population in Afromontane rain forest of Etiopia in relation to Colletotrichumkahawae and Gibberellaxylaroidus.Msc Thesis.Addis Ababa University, Etiopia.

Bayetta B. 2001.Arabica coffee breeding for yield and resistance to coffee berry disease PH.D.Thesis is submitted to imperial college at wye university of london.London,pp 54-77.

Berhanu, T. 2017. Ethiopian coffee sector strategy and prospects, Addis Ababa, Ethiopia. Availableat: $<$ https://afca.coffee/conference/wpcontent/uploads/presentations/2017/d1/Bir

Berthaud, J. and Charrier A. 1988.Genetic resources of Coffea.pp: 1-42. In: Clarke RJ, Macrae R (eds), Coffee: Agronomy, vol. IV, Elsevier Applied Science, London

Coste, R. 1992. Coffee plant and product. MacMillian, London.

Craparo, A.C.W, Van Asten PJA, Läderach P, Jassogne LTP, Grab SW.2015. Coffea arabica yields decline in Tanzania due to climate change: Global implications. Agric. For. Meteorol. 207:1-10.

CSA (Central statistical Agency).2007.The federal democratic republic of Ethiopia central statistical agency, agricultural sample survey 2006/2007 (1999 E.C.), volume I, report on area and production of major crops (private peasant holdings, meher season) statistical bulletin 588. Addis Ababa, Ethiopia.

CSA (Central statistical Agency).2011.The federal democratic republic of Ethiopia central statistical agency, agricultural sample survey 2010/2011 (2003 E.C.), volume I, report on area and production of major crops (private peasant holdings, meher season) statistical bulletin . Addis Ababa, Ethiopia.

CSA (Central statistical Agency).2012.The federal democratic republic of Ethiopia central statistical agency, agricultural sample survey 2011/2012 (2004 E.C.), volume I, report on area and production of major crops (private peasant holdings, meher season) statistical bulletin 532. Addis Ababa, Ethiopia.

CSA (Central statistical Agency).2013.The federal democratic republic of Ethiopia central statistical agency, agricultural sample survey 2012/2013 (2005 E.C.), volume I, report on area and production of major crops (private peasant holdings, meher season) statistical bulletin 532. Addis Ababa, Ethiopia.

CSA (Central statistical Agency).2014.The federal democratic republic of Ethiopia central statistical agency, agricultural sample survey 2013/2014(2006 E.C.), volume I, report on area and production of major crops (private peasant holdings, meher season) statistical bulletin 532. Addis Ababa, Ethiopia.

CSA (Central statistical Agency).2016.The federal democratic republic of Ethiopia central statistical agency, agricultural sample survey 2015/2016 (2008 E.C.), volume I, report on area and production of major crops (private peasant holdings, meher season) statistical bulletin 584. Addis Ababa, Ethiopia.

CSA (Central statistical Agency).2017.The federal democratic republic of Ethiopia central statistical agency, agricultural sample survey 2016/2017 (2009 E.C.), volume I, report on area and production of major crops (private peasant holdings, meher season) statistical bulletin 584. Addis Ababa, Ethiopia.

CSA (Central statistical Agency).2018. The federal democratic republic of Ethiopia central statistical agency, agricultural sample survey 2017/2018 (2010 E.C.), volume I, report on area and production of major crops (private peasant holdings, meher season) statistical bulletin 586. Addis Ababa, Ethiopia.

CSA (Central statistical Agency.2008.The federal democratic republic of Ethiopia central statistical agency, agricultural sample survey 2007/2008 (2000 E.C.), volume I, report on area and production of major crops (private peasant holdings, meher season) statistical bulletin 417. Addis Ababa, Ethiopia. 
CSA.2015.The federal democratic republic of Ethiopia central statistical agency, agricultural sample survey 2014/2015 (2007 E.C.), volume I, report on area and production of major crops (private peasant holdings, meher season) statistical bulletin 578. Addis Ababa, Ethiopia.

Damatta FM, Ramalho J.D.C. 2006. Impacts of drought and temperature stress on cofeee physiology and production: a review. Braz. J. Plant Physiol. 18:55-81.

Davis, A., Justin, M., Jenny, W., Susana, B., Timothy, W, Tadesse, W., Zeleke, K., Sebsebe, D. 2017. Effect of climate change on Arabica coffee specie in Ethiopia.

Dekens,J., MAK, $\quad$ F.B. 2012. Promoting an Integrated Approach to Climate Adaptation: Lessons from the coffee value chain in Uganda.

Eitzinger, A. Läderach, P. and Carmona S. 2013. Prediction of the impact of climate change on coffee and mango growing areas in Haiti. Centro Internacional de Agricultura Tropical(CIAT), Cali, Colombia.

Gianessi, L. Williams, A. 2011. Climate Change Increases Need for Fungicides for Coffee Trees.

Hadgu, G., Tesfaye, K., Mamo, G. and Kassa, B. 2013.Trend and variability of rainfall in Tigray, Northern Ethiopia: Analysis of meteorological data and farmers' perception. Academically Journal Environmental Science .1(8): 159-171.

ICO, 2014. Coffee Production Data. Www.ico.org. Accessed on June 15, 2017: International Coffee Organization.

Iscaro, J. 2014. The Impact of climate change on coffee production in Colombia and Ethiopia. Global Majority EJournal, 5(1):33-43.

Jaramillo, J., Eric, M., Fernando, E.V., Aaron. D., Christian, B., Adenirin, C. O. 2011. Some Like It Hot: The Influence and Implications of Climate Change on Coffee Berry Borer (Hypothenemus hampei) and Coffee Production in East Africa. PLOS ONE 6(9):1-14.

Kasterine, A., Scholer, M., Hilten, J.H. 2010. Climate Change and the Coffee Industry. Abstract for trade information services. International Trade Centre, Palais des Nations, 1211 Geneva 10, Switzerland.

Killeen, J.T., Harper, G. 2016. Coffee in the 21 st century. Will Climate Change and Increased Demand Lead to New Deforestation?

Läderach, P. Haggar, J., Lau, C. Eitzinger, A., Ovalle, O., Baca, M., Jarvis, A., Lundy, M. 2010. Mesoamerican coffee: Building a climate change adaptation strategy. CIAT Policy Brief no. 2.Centro International de Agricultura Tropical (CIAT), Cali, Colombia.

Partal, T. and Kahya, E. 2006. Trend analysis in Turkish precipitation data. Hydrological.Processes.20: 20112026.

USDA (United States Department of Agriculture), 2016. Coffee Production and Exports Remain Steady Report number ET 1615, Ethiopia.

Walyaro J. D. 2010. Climate change: potential impact on Eastern Africa coffees. Proceedings of the ASIC Conference

Yenigun, K., Gumus, V. and Bulut, H. 2008. Trends in stream flow of the Euphrates basin, Turkey. Proclamation Institute of Civil Engineering Water Management. 161:189-198.

Zewdu, Y. 2016. Explaining the Determinants of Ethiopia ${ }^{e e}$ s Coffee Export Performance and Potential.Ethiopian Coffee Exporters ${ }^{e e}$ Association. 